\title{
RESEARCH NOTE \\ Peteca rind pitting as influenced by proline content in winter lemon albedo
}

\author{
Thomas Fichet ${ }^{1}$, Jorge Chamorro ${ }^{2}$, and Alejandro Riquelme ${ }^{1}$ \\ ${ }^{1}$ Facultad de Ciencias Agronómicas, Universidad de Chile, Casilla 1004, Santiago, Chile. \\ ${ }^{2}$ Oppenheimer Co., 262 Chapman Rd, Bellevue \# 204, Newark, DE. 19702, USA.
}

\begin{abstract}
T. Fichet, J. Chamorro, and A. Riquelme. 2012. Peteca rind pitting as influenced by proline content in winter lemon albedo. Cien. Inv. Agr. 39(1): 201-209. One of the most important problems in lemon growing is the physiological disorder known as "peteca", which is characterized by causing cell dehydration and death in the albedo tissue with a subsequent necrosis of the surface zone of the fruit. This damage shows characteristics quite similar to those resulting from chilling injury in citrus fruit, where surface damage of fruit and dehydration of albedo cells also occur. Resistance to chilling injury shown by grapefruit would be related to increased proline content in the albedo (Purbis, 1981). In this study, proline content of lemons cv. "Fino" 49 from two groves, one in Curacaví $\left(33^{\circ} 25.778 \mathrm{~S}-71^{\circ} 02.292 \mathrm{~W}, 196 \mathrm{~m}\right.$ above


was analyzed and determined. The Curacaví grove had a low incidence of peteca, whereas the Mallarauco grove exhibited a high incidence of this disorder. Significant differences in albedo proline content were found between both groves and content of this amino acid was highly associated to the degree of peteca incidence. Proline might be playing a role in the lower incidence of "peteca" in winter lemon fruit.
\end{abstract}

Key words: Citrus limon, low temperatures, physiological disorder.

\section{Introduction}

"Peteca" is a physiological disorder affecting lemons from winter harvest, mainly in post-harvest (Undurraga et al., 2004). The precise cause inducing this problem is still not clear (Undurraga et al., 2004; Razeto, 2005; Undurraga et al., 2006). It has been associated to management in pre and post-harvest, climate conditions, along to calcium concentration, exposure, size and maturity of the fruit, even though the results are not conclusive

Received July 17, 2010. September 2, 2011. Corresponding author: tfichet@uchile.cl
(Wild, 1991, Razeto, 2005). On the other hand, it has been observed that different types of stress might increase the level of "peteca" (Undurraga et al., 2004).

During the development of this disorder, cells present a strong concentration of calcium oxalate, which might occur from the calcium from the cell walls and the vacuoles producing a collapse in the cell (Khalidy et al., 1969; Storey and Treeby, 2002). Then, dehydration takes place in the cells of the albedo and the subsequent collapse of the flavedo (Artes et al., 1981), finally causing small 
necrosed injuries in the fruit peel (Morales, 1985). On the other hand, manifestation of chilling injury in citrus fruits is expressed by a depression in the fruit epidermis, caused by a desiccation in the zone of the albedo (loss of water) and death of flavedo cells (Artes et al., 1981; Purvis and Yelenosky, 1983; Purvis, 1984). Cohen et al. (1994) indicate that, in some cases, a common denominator to both damages has been considered, as chilling injury in lemons and "peteca" are similar. Likewise, it has been observed that the manifestation of "peteca" (Cronjé, 2005) and the chilling injury (Purvis, 1984) do not present a uniform shape over the fruit surface, which be due to the diffusive resistance in the dehydration is not uniform, either (Purvis, 1980). On the other hand, there is some information on proline as an important element for protecting grapefruit against chilling injury (Purvis, 1981), manifesting a higher proline metabolism in fruits that are more tolerant to that injury (Purvis, 1983; Ezz et al., 2004). Proline is a cyclic alyphatic aminoacid (Mathews, 1998) that has been related as an agent of osmotic fit, due to its accumulation in the cytoplasm cells, which maintains the cell turgor (Sánchez-Díaz and Aguirreolea, 2000). Dierks-Ventling and Tonelli, (1982) indicate that proline is synthesized mainly from two precursors, glutamic acid, the most important, and ornithine or arginine (Hanson et al., 1977; Kavi-Kishort et al., 2005). Leaves fulfill the function of proline production, subsequently transporting to citrus fruit through the phloem (Purvis and Yelenosky, 1982; Servillo et al., 2011). But, the root is also mentioned as another site for synthesis in citrus fruits under water stress (Gimeno et al., 2009). Tadeo (2000) indicates that this amino acid maintains the membrane permeability favoring microviscosity or optimal flow. Hamilton and Heckathorn (2001) and, Sharma and Dietz (2006, cited by Gruzka et al., 2007) remark its antioxidant function, regulating capacity of the potential redox and defence against oxygen reactives, as well as its role on strengthening the membrane integrity (Hanson et al., 1977). It has been also indicated as a protective agent against desiccation and osmotic element in the cell (Purvis, 1981) and as an important way of energy to recover from stress (Sells and Koeppe, 1981; Kavi-Kishort et al., 2005).

Some geographic zones with low levels of "peteca" incidence are typically cold in fall, like the zone of Peumo (Region of O’Higgins). An abrupt change from a high temperature $\left(25^{\circ} \mathrm{C}\right)$ to a low temperature $\left(5{ }^{\circ} \mathrm{C}\right.$ ) during a week (Purvis and Yelenosky, 1983) has proved to be an important factor to generate increased proline levels.

As this element has multiple functions of protection and stabilization of the cell and associated to the tolerance of fruits against chilling injury, the relation between this amino acid and the manifestation of the "peteca" damage in winter lemons was studied.

\section{Materials and methods}

The experiments were performed in two commercial lemon tree orchards (Citrus limon L.) cv Fino 49, about 7 years old, located in the Metropolitan Region, Chile, between March and June of 2006. The first orchard belongs to the

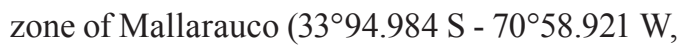
$269 \mathrm{~m}$ above sea level) and the second orchard to Curacaví $\left(33^{\circ} 25.778 \mathrm{~S}-71^{\circ} 02.292 \mathrm{~W}, 196\right.$ $\mathrm{m}$ above sea level). Both orchards are grafted onto Citrus macrophylla rootstock, at $6 \times 3 \mathrm{~m}$ (555 trees ha-1), drip irrigation ( $4 \mathrm{~L} \mathrm{~h}^{-1}$ drippers, each at 1 meter away) and plantation lines are North-South orientated, forming a hedge; therefore, there is only fruit between rows (East and West side of the trees). Between 2004 and 2006, "peteca" incidence in Curacaví was lower than 2\%, whereas in Mallarauco varied between 12 and $27 \%$ (Figure 1). The fruit presenting at least one "peteca" spot after 15 days from harvest was considered infected. Therefore, the percentage of incidence corresponded to the number of fruits showing, at least, one visible "peteca" over the total of fruits evaluated after 15 days of storage in refrigeration chambers of packing house. The 
monthly evolution of the mean minimum temperatures in Curacaví and Mallarauco in 2006 is presented in Figure 2.

Four samplings were made between May and

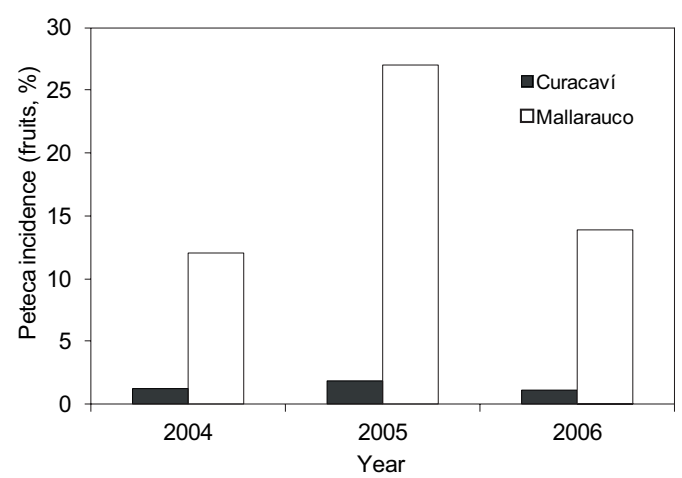

Figure 1. "Peteca" incidence, in fruit (\%), in lemons cv. Fino 49 from Curacaví and Mallarauco in the 2004, 2005 and 2006 seasons.

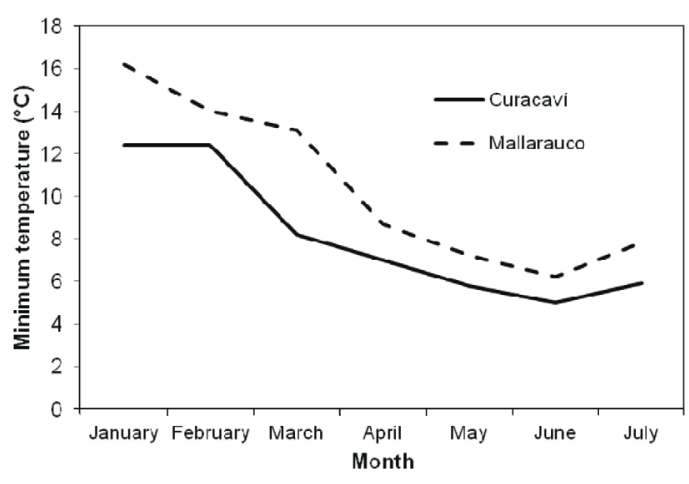

Figure 2. Monthy evolution of mean minimum temperaturas of the Curacaví1 ${ }^{1}$ and Mallarauco groves. Year 2006. Temperatures data of the Curacaví grove were obtained from the Meteorological Station of the Catholic University of Chile, closet o grove under study. Temperature at 8:00 a.m. was considered as the minimum temperature.

June of 2006, corresponding to commercial harvest, for the evaluation of the proline content. 12 fruits per orchard per evaluation were used, from 3 trees previously selected by their vigor, height, load and health condition, obtaining 4 fruits per tree, 2 from each exposure (East and
West). The work included fruits with similar shape and color, representative of the orchard, which were obtained from the tree periphery, at approximately between 1.5 and 1.7 height meters. The fruits were withdrawn along a piece of branch (approximately 5 to $8 \mathrm{~cm}$ long from the insertion with the fruit). The distal portion of the branch cut was placed in a Falcon tube, with $20 \mathrm{~mL}$ of distilled water and inside an electric fridge to maintain a constant temperature between 12 and $18^{\circ} \mathrm{C}$ to the laboratory. The chemical analyses were made in the Biochemical Laboratory of the Faculty of Agronomic Sciences of Universidad de Chile.

\section{Method of determination of proline concentration}

Firstly, a calibration curve was made between the free proline concentration and the absorbance values, determined by a spectrophotometer, obtaining a curve with $\mathrm{R}^{2}=0.974$. The procedure for extracting proline was made by the method described by Bates (1973), where the amount of used tissue was modified reducing the fruits albedo to $0.2 \mathrm{~g}$, which were not homogenized in $10 \mathrm{~mL}$, but $2 \mathrm{~mL}$ of sulfosalicylic acid at $3 \%$. The proline concentration was determined by the correlation between absorbance values and the proline concentration.

\section{Design and statistical analyses}

The experimental design was made in two orchards, where the fruit was the experimental unit.

The statistical analysis consisted on Student's $\mathrm{T}$ tests for the proline contents between the two orchards analyzed and by exposing the fruits in the tree independently for each orchard. Additionally, an analysis of correlation between the proline concentration in the fruits and the "peteca" incidence was made. 


\section{Results and discussion}

Relation between proline content and incidence of "peteca"

Significant differences were obtained in the proline contents in each date of measurement, among the fruits from each orchard under study (Figure 3).

The fruit from the Curacaví orchard presented levels statistically higher in their tissues (Figure 3), varying between 1.5 and $2.1 \mathrm{mg} \cdot \mathrm{g}^{-1}$ fresh weight, in comparison to the fruits from the Mallarauco orchard, which presented concentrations oscillating between 0.6 and $1.3 \mathrm{mg} \cdot \mathrm{g}^{-1}$ fresh weight. Additionally, the proline content showed a clear tendency to increase through time, based on the different dates of measurement and as long as the temperatures were diminishing. This accumulation of proline occurs as a result of the preventive action against low temperatures (Purbis, 1981; Mosbah et al., 1987; Ezz et al., 2004).

The temperatures in the Curacaví orchard were lower in comparison to the Mallarauco orchard as observed in Figure 2, presenting an approximate difference of $2{ }^{\circ} \mathrm{C}$ in the minimum temperatures, between March and April. This thermal differential might be part of the different proline concentrations among fruits from the two orchards

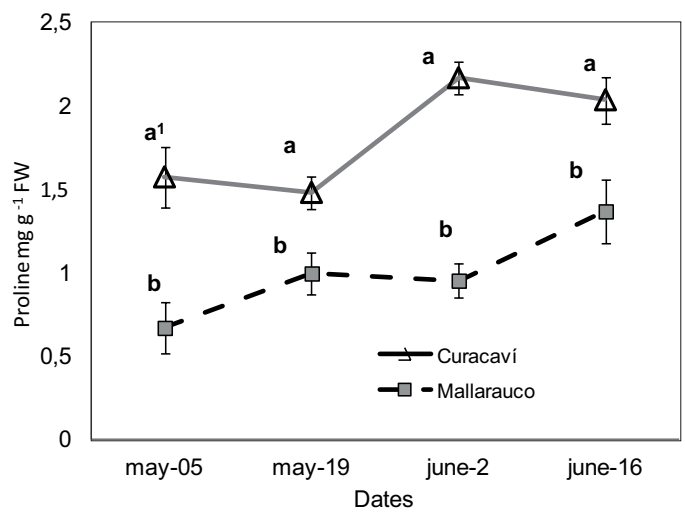

Figure 3. Proline concentration in the albedo of lemons cv. Fino 49 from Curacaví and Mallarauco at four measurement dates. Year 2006. Means \pm SE, $n=12$. ${ }^{1}$ Different letters for a same date indicate significant differences using student's t $(5 \%)$ between localities. studied. The accumulation of this amino acid in the lemons albedo occurs due to the proline translocation from the leaves towards the fruits, which is stimulated after some exposure to low temperatures, especially with values lower than $10^{\circ} \mathrm{C}$ (Purvis and Yelenosky, 1982). Previously, the plant increases the proline concentration in the leaves, as a mechanism of gradual acclimation, before carrying it towards different organs. After an analysis of Figure 2 and with an average minimum temperature of $7^{\circ} \mathrm{C}$ as reference, it is observed that the Curacaví orchard presents this temperature during April; on the other hand, the Mallarauco orchard shows this temperature only during June, which might allow the trees from the first orchard to acclimate before and for a longer period, favoring a higher proline production this period. This behavior might be also associated to the evolution in proline concentration in the curve of the Mallarauco fruits, where an increased proline concentration through the four dates of measurement is evident, until reaching a content of $1.3 \mathrm{mg} \cdot \mathrm{g}^{-1}$ of fresh weight. This is similar to the concentration observed in the first measurement in Curacaví (1.5 $\mathrm{mg} \cdot \mathrm{g}^{-1}$ of fresh weight) made on May 5, with a delay of essentially 45 days between localities. Based on these results, the variable temperature could be studied more deeply in future works as a tool allowing the prediction of an eventual "peteca" occurrence in lemon orchards.

The average proline concentration in the albedo from each measurement was correlated with the corresponding index of "peteca" incidence, in order to analyze the possible effect of the concentration as a regulator of that incidence, presenting a good degree of association between both parameters (Figure 4). It was observed that the degree of "peteca" incidence in the fruit decreases, as the proline content in the albedo tissues increases, indicating that it might be an interaction between this amino acid with some cell constituents, which might generate a lower response to the damage by "peteca", as proline diminishes the consequences and disturbances caused by dehydration in the 
cells, as well as it interacts with some enzymes, favoring the structure preservation and activity of the membrane, protecting the cell walls structurally and functionally (Stewart and Lee, 1974; Chadalavada et al., 1994; Hamilton and Heckathorn, 2001). Additionally, it has been observed that proline might act increasing the cell osmolarity, helping provide the necessary turgor for cell stability and growth (Hanson et al,. 1977). Carpenter and Crowe (1988, cited by Kurt and Hanson, 1997) indicate that this amino acid is essential for stabilizing cell structures, presenting an osmoprotector and cryoprotector activity in fruits tissues, as well as cell protection against oxygen reactives and free radicals (Withers and King, 1979; Alia and Mohanty, 1997). This is important if we consider that damage by "peteca" has been associated to the action of oxygen reactives and a lack of oxygen diffusion in the cells (Nobel, 1999, cited by Storey and Treeby, 2002).

To date, diverse research has been made in order to diminish the incidence of this important disorder, as, for instance, through the increase in the calcium content in the fruit (Undurraga et al., 2006), fruits brushing or wax applications (Wild, 1991), without positive effects for diminishing this disorder. Therefore, associating the concentration of this amino acid to the "peteca" manifestation may be important as a tool to counteract the serious damaged caused by this physiological disorder, as well

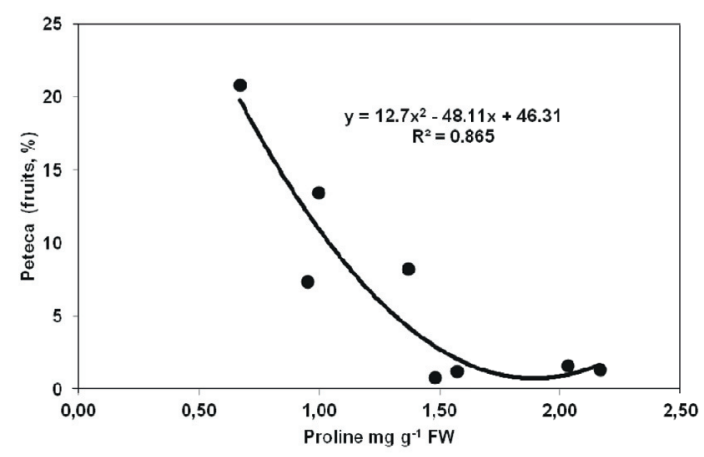

Figure 4. "Peteca" incidence for different harvest dates, as a function of mean concentration of albedo proline, in lemons cv. Fino 49 from Curacaví and Mallarauco. Year 2006. $\mathrm{n}=8$. as researching the type of agronomic management may increase the proline content in fruits, or the varieties presenting a higher synthesis capacity. Thus, diverse management has been studied in other species to increase the proline levels (Purvis and Yelenosky, 1982; Correa et al., 2004; Su and Wu, 2004; Gruzka et al., 2007). Differences in the capacity from the varieties in the synthesis of this amino acid (Hanson et al., 1977), their implications for genetic improvement (Nolte and Hanson, 1997) and the genes involved in their transportation (Schwacke et al., 1999; Sharma et al., 2011) have been also researched, showing some interesting elements, mainly by studying the transportation of proline towards the fruits and increased expression of this amino acid through the water deficit (Gimeno et al., 2009).

One aspect that should be studied is the new research carried out with exogen applications of proline made in other species, obtaining good results that might contribute to know the behavior of this amino acid and its relation with the manifestation of "peteca" better, and promising to be an additional alternative to the genetic improvement (Gadallah, 1999; Okuma et al., 2004; Takeuchi et al., 2008). The increase of the proline content in apples has also been achieved, by the foliar application of glicyne-betaine, abscisic acid (ABA), salicilic acid and oxalic acid (Jie et al., 2008), which might indicate feasible increases in the content of this amino acid in fruits, through the possible use of commercial bioregulators like ABA.

Another interesting element to cover is the fact that proline accumulation occurs not only in citrus fruits, but also from another osmoprotector, proline-betaine, which represents approximately $20 \%$ of the total proline in lemon (Nolte and Hanson, 1997). This osmolite is important because there is evidence of an even better osmoprotector capacity in the cells, as it is synthesized from proline (Nolte and Hanson, 1997) and with a good response against exogen applications (Okuma 
et al., 2004), and that, additionally, it maintains constant against temperatures triggering a higher proline content (Nolte and Hanson, 1997). The use of glicyne-betaine in lemons, which has been successfully tested in foliar applications in tomato and wheat, might be also explored, (Makelfa et al., 1996), inducing and increased final content of proline (Jie et al., 2008; Demiral and Türkal, 2006).

\section{Proline content in fruits modified by exposure}

Some authors (Wild, 1991; Razeto, 2005) indicate that factors as the position within the canopy and vigor of the tree might be influencing the development and manifestation of "peteca", along climate. Therefore, comparing the levels of proline among fruits from the East exposure of the tree and others with West exposure was pertinent (Table 1). However, differences were not detected and some evidence on this variable was neither observed, determining insubstantial data. In view of these results, the exposure of the fruit might not be an essential factor in the expression or accumulation of proline in the fruit, because, temperature is an important factor for increasing proline, as Purvis and Yelenosky mentioned (1983). Lower temperatures would favor an increase of this amino acid in the plant and the difference in temperature possibly generated between each exposure, might be insignificant to induce differences in the proline contents in fruits. Additionally, it needs to be considered that the production of this amino acid does not occur in the fruit, but produced initially in the leaves and then transported to the fruit (Talmadge et al., 1973) via phloem (Sharma et al., 2011). Therefore, if the plant is exposed to lower temperatures in some of the two exposures, it might stimulate the proline synthesis through the entire tree, distributing homogeneously and not only in one sector. However, as Razeto (2005) points out in regard to the fruits of the tree interior presenting a behavior against "peteca" different to the fruits located in the tree exterior, it might perfectly be due to different levels of proline; therefore the minimum temperatures of the interior of the lemon tree are higher than the tree periphery.

Based on the results obtained, and under the conditions how this experiment was made, it may be concluded that the lower incidence of "peteca" in lemon fruits from winter harvest, relates to the proline content in the el albedo. On the other hand, the different environmental conditions prevail, in regard to the occurrence of low temperatures, also define differences in the incidence of the disorder "peteca" in the albedo of lemon fruits.

Table 1. Proline concentration in the albedo of lemons cv. Fino 49 from Curacaví and Mallarauco, and with two different tree exposures, at four measurement dates. Year 2006. $\mathrm{n}=3$.

\begin{tabular}{|c|c|c|c|c|c|}
\hline \multirow{2}{*}{ Groves } & \multirow{2}{*}{ Exposures } & \multicolumn{4}{|c|}{ Proline concentration } \\
\hline & & May-05 & May-19 & Jun-02 & Jun-16 \\
\hline \multirow{3}{*}{ Curacaví } & & \multicolumn{4}{|c|}{$\mathrm{mg} \mathrm{g}^{-1}$ peso fresco } \\
\hline & East & $1.627 \pm 0.19 \mathrm{a}^{1}$ & $1.395 \pm 0.10 \mathrm{a}$ & $2.190 \pm 0.06 \mathrm{a}$ & $2.064 \pm 0.10 \mathrm{a}$ \\
\hline & West & $1.519 \pm 0.18 \mathrm{a}$ & $1.564 \pm 0.09 \mathrm{a}$ & $2.144 \pm 0.10 \mathrm{a}$ & $2.005 \pm 0.18 \mathrm{a}$ \\
\hline \multirow[t]{2}{*}{ Mallarauco } & East & $0.639 \pm 0.16 \mathrm{a}$ & $1.121 \pm 0.12 \mathrm{a}$ & $1.058 \pm 0.11 \mathrm{a}$ & $1.249 \pm 0.20 \mathrm{a}$ \\
\hline & West & $0.700 \pm 0.17 \mathrm{a}$ & $0.900 \pm 0.14 \mathrm{a}$ & $0.849 \pm 0.10 \mathrm{a}$ & $1.486 \pm 0.18 \mathrm{a}$ \\
\hline
\end{tabular}

${ }^{1}$ Means \pm S.E. within each column and grove, followed by the same letters for different tree exposures, are not significantly different using Studen's t (5\%). 


\section{Resumen}

T. Fichet, J. Chamorro y A. Riquelme. 2012. Influencia del contenido de prolina en el albedo de limón de invierno sobre el desarrollo de peteca. Cien. Inv. Agr. 39(1):201-209. Uno de los problemas más importantes en la producción de limones es el desorden fisiológico denominado "peteca", el que se caracteriza por producir una deshidratación y muerte celular en la zona del albedo, con una posterior necrosis en la zona superficial del fruto. Este daño manifiesta características muy similares a las que se evidencian en el daño por frío en fruta cítrica, en donde también se produce un daño superficial del fruto y se evidencia una deshidratación en las células del albedo. Se observó relación existente entre la resistencia que manifiesta la fruta cítrica, frente al daño por frío, con el incremento en el contenido de prolina en la corteza del fruto. En este estudio se determinó y analizó los contenidos de prolina en limones var. Fino 49 de dos p, uno en Curacaví (S 3325.778 - W 7102.292; 196 m.s.n.m.) caracterizado por un historial de baja incidencia de "peteca", y otro en Mallarauco (S 3394.984 - W 7058.921, 269 m.s.n.m.) caracterizado por una alta incidencia de este desorden. Se determinaron diferencias significativas entre los contenidos de prolina de ambos huertos y se evidenció un alto grado de asociación entre la concentración de este aminoácido en el albedo y el grado de incidencia de "peteca". La prolina podría estar jugando un papel en la menor incidencia de "peteca" en limones de cosecha invernal.

Palabras clave: Aclimatación, bajas temperaturas, Citrus limon, desorden fisiológico.

\section{References}

Alia, P., and P. Mohanty. 1997. Involvement of proline in protecting thylakoid membranes against free radical-induced photodamage. Journal of Photochemistry and Photobiology 38: 253-257.

Artes, F., M. Guillen, and A. Escriche. 1981. Physiological disorders in the storage of lemon fruits. 2: 768-772. In: International Citrus Congress. Tokyo, Japón. Noviembre 1981. International Society of Citriculture. 938 pp.

Bates, L. 1973. Rapid determination of free proline for water stress studies. Plant and Soil 39: $205-$ 207.

Chadalavada, S., B. Rajendrakumar, V. Reddy, and A. Reddy. 1994. Proline-protein interactions: protection of structural and functional integrity of M4 lactate dehydrogenase. Biochemistry and Biophysiology Research Community 201: 957-963.

Cohen, E., B. Shapiro, Y. Shalom, and J. Klein. 1994. Water loss: A nondestructive indicator of enhanced cell membrane permeability of chilling injured citrus fruit. Journal of the American Society for Horticultural Science 119: 983-986.
Correa, H., C. Marura, J. Bespalhok, and A. Kobayashib. 2004. Osmotic adjustment in transgenic citrus rootstock Carrizo citrange (Citrus sinensis Osb. x Poncirus trifoliata L. Raf.) overproducing proline. Plant Science 167: 1375-1381.

Cronjé, P. 2005. Peteca spot of lemons. SA Fruit Journal 2005(3): 26-28.

Demiral, T., and I. Türkan. 2006. Exogenous glycinebetaine affects growth and proline accumulation and retards senescence in two rice cultivars under $\mathrm{NaCl}$ stress. Environmental and Experimental Botany 56: 72-79.

Dierks-Ventling, C., and C. Tonelli. 1982. Metabolism of proline, glutamate, and ornithine in proline mutant root tips of Zea mays (L.). Plant Physiology 69: 130-134.

Ezz, M., A. Ritenour, and J. Brecht. 2004. Hot water and elevated $\mathrm{CO}_{2}$ effects on proline and other compositional changes in relation to postharvest chilling injury of "Marsh" grapefruit. Journal of American Society of Horticultural Science 129(4): 576-582.

Gadallah, I. 1999. Effects of proline and glycinebetaine on Vicia faba responses to salt stress. Biologia Plantarum 42 (2): 249-257. 
Gimeno, J., J. Gadea, J. Forment, J. Pérez-Valle, J. Santiago, M. Martínez-Godoy, L. Yenush, J. M. Bellés, J. Brumós, J. M. Colmeros-Flores, M. Talón, and R. Serrano. 2009. Shared and novel molecular responses of mandarin to drought. Plant. Mol. Biol. 70: 403-420.

Gruzka, E., I. Schusterbs, M. Pileggic, C. Scapimd, H. Correa, C. Jamil, and L. Estevez. 2007. Stressinduced synthesis of proline confers tolerance to water deficit in transgenic wheat. Journal of Plant Physiology 164(10): 1367-1376.

Hamilton, E., and S. Heckathorn. 2001. Mitochondrial adaptations to $\mathrm{NaCl}$. Complex I is protected by antioxidants and small heat shock proteins, whereas complex II is protected by proline and betaine. Plant Physiology 126: 1266-1274.

Hanson, A., C. Nelsen, and E. Everson. 1977. Evaluation of free proline as an index of drought resistance using two barley cultivars. Crop Science 17: 720-726.

Jie, Y., H. Yang, H. Zhao, W. Zhang, and D. Li. 2008. Promotion in apple leaves by bioregulators. Acta Horticulturae 774: 237-242.

Kavi Kishort, P., S. Sangam, R. Amrutha, P. Sri Laxmi, K. Naidu, K. Rao, S. Rao, K. Reddy, P. Theriappan, and N. Sreenivasulu. 2005. Regulation of proline biosynthesis, degradation, uptake and transport in higher plants: Its implications in plant growth and abiotic stress tolerance. Current Science 88 (3): 424-438.

Khalidy, R., A. Jamali, and H. Bolkan. 1969. Causes of the peteca disease of lemons ocurring in Lebanon. Proceedings of the First International Citrus Symposium 2: 1253-1261.

Kurt, N., and A. Hanson. 1997. Proline accumulation and methylation to proline betaine in citrus: implication for genetic engineering of stress resistance. Journal of American Society for Horticultural Science 122 (1): 8-13.

Makelfa, P., P. Peltonen-Sainio, K. Jokinen, E. Pehu, H. Setala, R. Hinkkanen, and S. Somersalo. 1996. Uptake and translocation of foliar-applied glycinebetaine in crop plants. Plant Science 121 (2): 221-230.

Mathews, C. 1998. Bioquímica. Ed. McGraw-Hill Interamericana, Madrid, España. 1283 pp.
Morales, A. 1985. Principales enfermedades bióticas y abióticas en limones. Revista Frutícola 6(2): 55-59.

Mosbah, M., M. Kushad, and G. Yelenosky. 1987. Evaluation of polyamine and proline levels during low temperature acclimation of citrus. Plant Physiology 84(3): 692-695.

Nolte, K., and A. Hanson. 1997. Proline accumulation and methylation to proline betaína in Citrus: Implications for genetic engineering of stress resistance. Journal of American Horticultural Science 122 (1): 8-13.

Okuma, E., Y. Murakami, Y. Shimoishi, M. Tada, and Y. Murata. 2004. Effects of exogenous application of proline and betaine on the growth of tobacco cultured cells under saline conditions. Soil Science and Plant Nutrition 50(8): 1301-1305.

Purvis, A. 1980. Influence of canopy depth on susceptibility of "Marsh" grapefruit to chilling injury. HortScience 15: 731-733.

Purvis, A. 1981. Free proline in peel of grapefruit and resistance to chilling injury during cold storage. HortScience 16(2): 160-161.

Purvis, A. 1983. Effects of film thickness and storage temperature on water loss and internal quality of seal-packaged grapefruit. Journal of American Society of Horticultural Science 108 (4): 562-566.

Purvis, A. 1984. Importance of water loss in the chilling injury of grapefruit stored at low temperature. Scientia Horticulturae 23: 261-267.

Purvis, A., and G. Yelenosky. 1982. Sugar and proline accumulation in grapefruit flavedo and leaves during cold hardening of young trees. Journal of American Society of Horticultural Science 107(1): 222-226.

Purvis, A., and G. Yelenosky. 1983. Translocation of carbohydrates and proline in young grapefruit trees at low temperatures. Plant Physiology 73: 877-880.

Razeto, B. 2005. El Limonero. Bruno Razeto, Ediciones y Comercialización de Libros. Santiago, Chile. 215 pp.

Sánchez-Díaz, M., and J. Aguirreolea 2000. Transporte de agua y balance hídrico en la planta. pp. 45-64. In: Azcón-Bieto, J., and M. Talón (eds.). Fundamentos de fisiología vegetal. 
McGraw-Hill-Interamericana. Madrid, España. $521 \mathrm{pp}$.

Servillo, L., A. Giovane, M.L. Balestrieri, D. Cautela, and D. Castaldo. 2011. Proline derivatives in fruits of bergamot (Citrus bergamia Risso et Poit): presence of N-methyl-L-proline and 4-hydroxy-L-prolinebetaine. J. Agric. Food Chem. 59 (1): 274-281.

Schwacke, R, S. Grallath, K. Breitkreuz, E. Stransky, H. Stransky, W. Frommer, and D. Rentsch. 1999. LeProT1, a transporter for proline, glycine betaine, and g-amino butyric acid in tomato pollen. The Plant Cell 11: 377-391.

Sells, G.D., and D. E. Koeppe. 1981. Oxidation of proline by mitochondria isolated from waterstresses maize shoots. Plant Physiology 68: 1058-1063.

Sharma, S., J. Villamor, and P. Verslues. 2011. Essential role of tissue specific proline synthesis and catabolism in growth and redox balance at low water potential. Plant Physiology in press.

Stewart, G., and J. Lee. 1974. The role of proline accumulation in halophytes. Planta 120: 279-289.

Storey, R., and M. Treeby. 2002. Cryo-SEM study of early symptoms of peteca spot in "Lisbon" lemon. Journal of Horticultural Science and Biotechnology 77 (5): 551-556.

$\mathrm{Su}$, J., and R. Wu. 2004. Stress inducible synthesis of proline in transgenic rice confers faster growth under stress conditions than with constitutive synthesis. Plant Science 166: 941-948.
Tadeo, F. 2000. Fisiología de las plantas y el estrés. pp. 481-498. In: Azcón-Bieto, J., and M. Talón (eds.). Fundamentos de fisiología vegetal. McGraw-HillInteramericana. Madrid, España. 521 pp.

Talmadge, K., K. Keegstra, W. Bauer, and P. Albersheim. 1973. The structure of plant cell walls I. The Macromolecular Components of the Walls of Suspension-cultured Sycamore Cells with a Detailed Analysis of the Pectic Polysaccharides. Plant Physiology 51: 158-173.

Takeuchi, M., C. Arakawa, Y. Kuwahara, and H. Gemma. 2008. Effects of L-Proline foliar application of the quality of "Kosui" Japanese pear. Acta Horticulturae 800:549-554.

Undurraga, P., J. Olaeta, and J. Retamales. 2004. Peteca: Un desorden fisiológico en limones. Avance Agrícola 124: 16-18.

Undurraga, M., J. Olaeta, J. Retamales, and A. Brito. 2006. Efecto de inmersiones en calcio sobre "peteca" en limones amarillos y plateados, cosechados después de una lluvia y almacenados en refrigeración. Agricultura Técnica (Chile) 6(1): 3-12.

Wild, B. 1991. Postharvest factors governing the development of peteca rind pitting on "Meyer" lemons. HortScience 26(3): 287-289.

Withers, L., and J. King. 1979. Proline: A novel cryoprotectant for the freeze preservation of cultured cells of zea mays. Plant Physiology 64: 675-678. 
